\title{
Article \\ Prevalence and Antibiogram of Vibrio parahaemolyticus and Aeromonas hydrophila in the Flesh of Nile Tilapia, with Special Reference to Their Virulence Genes Detected Using Multiplex PCR Technique
}

\author{
Hanan A. Zaher ${ }^{1}$ (D), Mohamad I. Nofal ${ }^{2}$, Basma M. Hendam ${ }^{3}$, Moustafa M. Elshaer ${ }^{4}$, Abdulaziz S. Alothaim ${ }^{5, *}$ \\ and Mostafa M. Eraqi $5,6, *$ D \\ 1 Food Hygiene and Control Department, Faculty of Veterinary Medicine, Mansoura University, \\ Mansoura 35516, Egypt; hananzaher@mans.edu.eg \\ 2 General Authority of Fish Resources and Development (GAFRD), Manzala Fish Farm, Manzala 35642, Egypt; \\ aemohamadonofal@yahoo.com \\ 3 Department of Husbandry and Development of Animal Wealth, Faculty of Veterinary Medicine, \\ Mansoura University, Mansoura 35516, Egypt; basmahendam@mans.edu.eg \\ 4 Department of Microbiology at Specialized Medical Hospital, Mansoura University, Mansoura 35516, Egypt; \\ moustafaelshaer@mans.edu.eg \\ check for \\ updates \\ Citation: Zaher, H.A.; Nofal, M.I.; \\ Hendam, B.M.; Elshaer, M.M.; \\ 5 Department of Biology, College of Science in Zulfi, Majmaah University, Majmaah 11952, Saudi Arabia \\ 6 Microbiology and Immunology Department, Veterinary Research Division, National Research Centre, \\ Dokki, Giza 12622, Egypt \\ * Correspondence: a.alothaim@mu.edu.sa (A.S.A.); m.eraqi@mu.edu.sa (M.M.E.); \\ Tel.: +96-654-8653335 (A.S.A.); +96-656-5709849 (M.M.E.)
} Alothaim, A.S.; Eraqi, M.M. Prevalence and Antibiogram of Vibrio parahaemolyticus and Aeromonas hydrophila in the Flesh of Nile Tilapia, with Special Reference to Their Virulence Genes Detected Using Multiplex PCR Technique. Antibiotics 2021, 10, 654. https://doi.org/ 10.3390/antibiotics10060654

Academic Editors: Olumide Odeyemi and Deyan Stratev

Received: 12 April 2021

Accepted: 26 May 2021

Published: 30 May 2021

Publisher's Note: MDPI stays neutral with regard to jurisdictional claims in published maps and institutional affiliations.

Copyright: () 2021 by the authors. Licensee MDPI, Basel, Switzerland. This article is an open access article distributed under the terms and conditions of the Creative Commons Attribution (CC BY) license (https:// creativecommons.org/licenses/by/ $4.0 /)$.

\begin{abstract}
Vibrio parahaemolyticus and Aeromonas hydrophila are major public health problems and the main cause of bacterial disease in Nile tilapia (Oreochromis niloticus). This study was conducted to determine the prevalence, antibiotic resistance and some virulence genes of both $V$. parahaemolyticus and A. hydrophila isolates from Nile tilapia. From Manzala Farm at Dakahlia governorate, 250 freshwater fish samples were collected. The confirmed bacterial isolates from the examined Nile tilapia samples in the study were $24.8 \%(62 / 250)$ for V. parahaemolyticus and $19.2 \%(48 / 250)$ for A. hydrophila. multiplex PCR, revealing that the th gene was found in $46.7 \%(29 / 62)$ of $V$. parahaemolyticus isolates, while the $t d h$ and $t r h$ virulence genes were found in $17.2 \%(5 / 29)$. Meanwhile, $39.5 \%(19 / 48)$ of $A$. hydrophila isolates had the $16 \mathrm{~s} r \mathrm{RNA}$ gene and $10.5 \%(2 / 19)$ had the aer $A$ and ahh1 virulence genes. The Multiple Antibiotic Resistance indices of V. parahaemolyticus and A. hydrophila were 0.587 and 0.586 , respectively. In conclusion, alternative non-antibiotic control strategies for bacterial infections in farmed fish should be promoted to avoid multidrug-resistant bacteria. Therefore, it is suggested that farmers should be skilled in basic fish health control and that molecular detection methods are more rapid and cost-effective than bacteriological methods.
\end{abstract}

Keywords: molecular identification; Aeromonas hydrophila; Vibrio parahaemolyticus; Oreoch- romis niloticus

\section{Introduction}

Aquaculture is a globally essential industry that provides food to the world's rapidly growing population, in addition to being a good source of low-cost animal protein [1]. Nile tilapia (Oreochromis niloticus) is the second-largest aquatic species cultivated worldwide [2,3]. The overall production of farmed Nile tilapia in Egypt accounts for 71.2 percent of all farmed Nile tilapia worldwide [4] and is the source of the most common strains and species used in commercial aquaculture. In general, seafood is a notable source of pathogenic microorganisms infectious to humans [5,6]. Cultivation of fish may pose some fish health problems due to contamination by pathogenic bacteria, which leads to high economic 
losses [7]. Contamination can occur at any time during the collection, storage or distribution of seafood and may come from water, facilities, machinery and handlers. Feces containing spoilage microorganisms and pathogens may contaminate seafood and cause microbial contamination [8]. Freshwater tilapia in Egypt is often exposed to a variety of possible stressors, including inadequate management and environmental factors that reduce natural immunity, resulting in disease and death in the fish [9]. The key environmental parameters are increased turbidity, temperature, salinity, $\mathrm{pH}$, water conductivity and lower dissolved oxygen [4]. Tilapia, under stress factors, is susceptible to many bacterial diseases that are common in the freshwater ecosystem [10]. Bacteria are responsible for huge mortalities in fish species resulting in higher economical loss in aquaculture [11]. However, bacteria are not the only main cause of infection in fish; viruses also have a major role in aquaculture contamination. The major viral fish diseases in aquaculture have been reported in many reviews [12-16].

$V$. parahaemolyticus is out of the most common causes of salty, brackish and freshwater fish diseases [17]. The usual clinical signs of the V. parahaemolyticus toxin in humans include acute dysentery and stomach ache, followed by diarrhea, nausea, vomiting, fever, chills and watery stool [18]. The genes responsible for haemolysin, comprise thermostable direct-haemolysin $(t d h)$, TDH-related haemolysin $(t r h)$ and thermolabile haemolysin $(t h)$, performs an essential role in pathogenesis $[19,20]$. In this regard, $V$. parahaemolyticus strains possess some virulence factors as $t d h$ and $t r h$ [21], that are linked mainly to hemolysis and cytotoxicity in the host cell [22]. This means that most V. parahaemolyticus found in clinical cases carry trh or $t d h$ genes [23]. Detection of the presence of Vibrio in a food sample is usually performed by selective media like thiosulphate citrate bile salts sucrose (TCBS) media, and then confirmed by biochemical assays [24,25]. Aeromonas spp. causes more severe bacterial diseases that influences various fish and shellfish species, posing a serious threat to Egypt's and other countries' fish farming industries [26]. A. hydrophila, on the other hand, is a zoonotic pathogen belonging to the Aeromonadaceae family [27-30], which is considered the most important cause of gill and skin disease, causing high mortality rate in freshwater fish [31]. It may cause intestinal and extra-intestinal diseases in humans, such as septic arthritis, diarrhea (traveler's diarrhea), gastroenteritis, meningitis, septicemia and skin and wound infections [32]. Virulence factors like DNases, hemolysin, proteases, aerolysin and lipases has been corelated with the pathogenicity of Aeromonas spp. Such toxins play a critical role in the development of diseases in fish and humans [33,34]. 16S rRNA is a suitable marker for Aeromonas spp. identification [35]. Antibiotics are widely utilized in seafood farms as feeding additives or to prevent bacterial diseases [36], but extreme usage of antibiotics resulted in the evolution of drug resistance in aquaculture pathogenic strains, which has become a serious problem for veterinary and human health [37]. The Multiple Antibiotic Resistance (MAR) Index is considered as a useful way to evaluate contamination sources [38]. This study aimed to detect the prevalence and antibiotic-resistant patterns of $V$. parahaemolyticus and A. hydrophila in Nile tilapia samples collected from Manzala Farm at Dakhalia governorate. Moreover, the presence of certain virulence factors was investigated using the multiplex PCR technique for detecting the occurrence of this important seafood-borne pathogen and providing a fortuitous opportunity to high-risk environments and consequently reducing the risk of food-borne illness.

\section{Results}

\subsection{The Environmental Parameter at Manzala Farm}

These data were taken from the farm administrator: Oxygen $=3 \mathrm{mg} / \mathrm{L}, \mathrm{PH}=9.1$, Temp $=33{ }^{\circ} \mathrm{C}$, Salinity $1.3 \mathrm{~g} / \mathrm{L}, \mathrm{NH} 3=$ over range (more than $1 \mathrm{mg} / \mathrm{L}$ ), NH4 = over range (more than $1 \mathrm{mg} / \mathrm{L})$, Copper $=1.2 \mathrm{mg} / \mathrm{L}$, Hardness = more than $500 \mathrm{mg} / \mathrm{L}$, Iron $=1.3 \mathrm{mg} / \mathrm{L}$, Nickel $=1.55 \mathrm{mg} / \mathrm{L}$, Phosphates $=2 \mathrm{mg} / \mathrm{L}$, Sulfide $=0.4 \mathrm{mg} / \mathrm{L}$, Nitrite $=0.75 \mathrm{mg} / \mathrm{L}$, Zinc $=0.3 \mathrm{mg} / \mathrm{L}$. All these environmental parameters are above the permissible levels. The mortality rate was about $10 \%$ because of poor storage in ponds and the use of agricultural drainage water as a resource for pond water. 


\subsection{Clinical Signs and Postmortem Examination of Diseased Tilapia}

Postmortem examination showed a congested liver with hemorrhage on its surface and engorged gall bladder with splenic hemorrhage. The kidney was also congested and enlarged in the case of $V$. parahaemolyticus (Figure 1a,b), while the clinical signs of naturally infected fish with Aeromonas were hemorrhagic septicemia in the form of bilateral exophthalmia with gill cover hemorrhage, eye clouding, hemorrhage, surface ulcers, abdominal distension and massive mortality (Figure 1c,d).
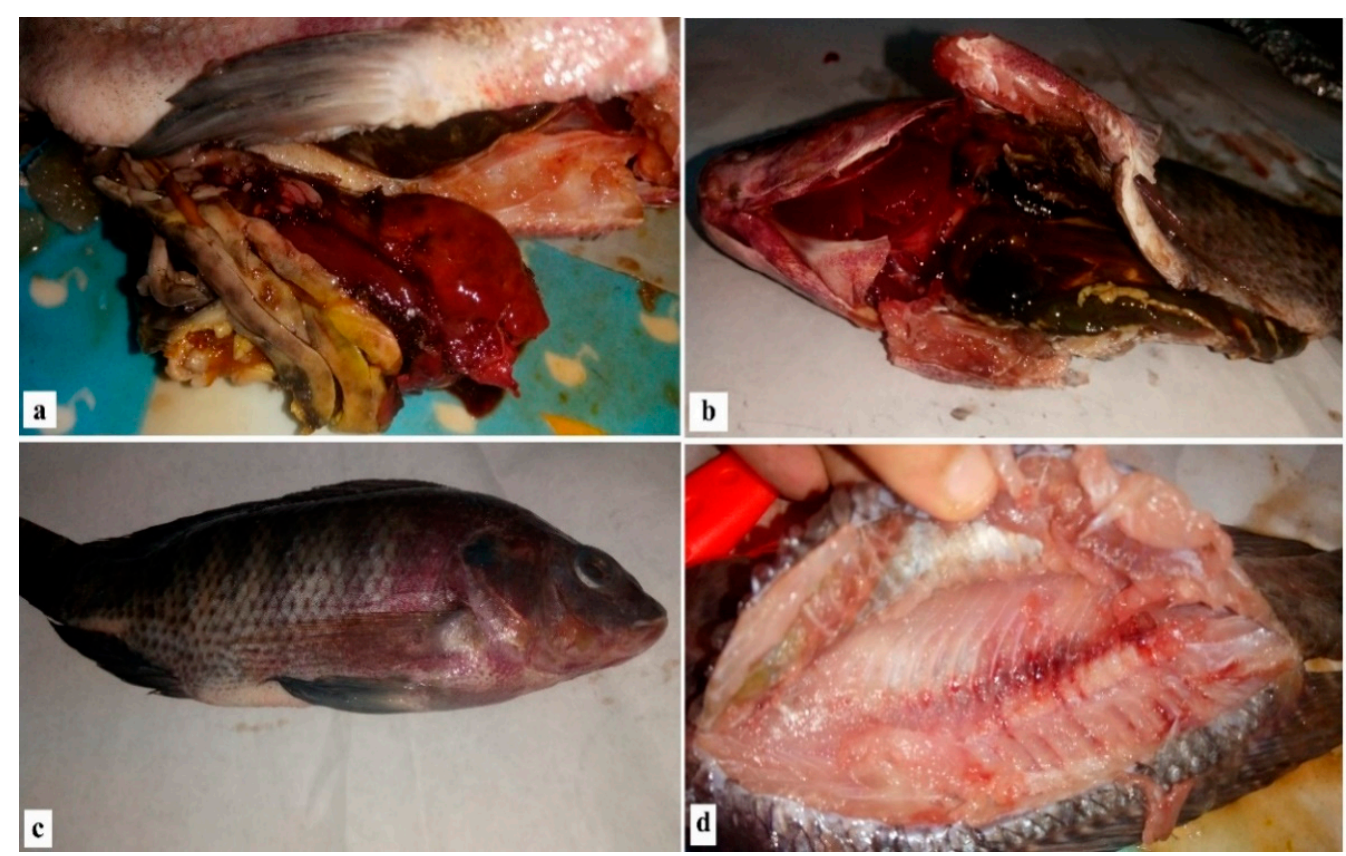

Figure 1. Clinical signs and postmortem examination of diseased Nile tilapia.

2.3. Prevalence of Comfirmed Isolates of V. parahaemolyticus and A. hydrophila in the Examined Nile tilapia Based on Biochemical Tests

In this study, the detectable prevalence rates of confirmed isolates of $V$. parahaemolyticus and A. hydrophila were 24.8\% (62/250) and 19.2\% (48/250), respectively (Table 1; Figure 2).

Table 1. Prevalence and molecular identification of confirmed isolates of $V$. parahaemolyticus and $A$. hydrophila in Nile tilapia $\left(n^{*}=250\right)$.

\begin{tabular}{|c|c|c|c|c|c|c|}
\hline \multirow{2}{*}{ Isolates } & \multicolumn{2}{|c|}{ Confirmed Isolates } & \multicolumn{2}{|c|}{$\begin{array}{c}\text { Strains Containing } t l h \\
\text { Gene }\end{array}$} & \multicolumn{2}{|c|}{$\begin{array}{l}\text { Strains Containing } t d h \\
\text { and } t r h \text { Genes }\end{array}$} \\
\hline & $n$ & $\%$ & $n$ & $\%$ & $n$ & $\%$ \\
\hline V. parahaemolyticus & 62 & 24.8 & 29 & 46.7 & 5 & 17.2 \\
\hline \multirow[t]{2}{*}{ A. hydrophila } & & & \multicolumn{2}{|c|}{$\begin{array}{l}\text { Strains contain } 16 S \\
\quad r R N A \text { gene }\end{array}$} & \multicolumn{2}{|c|}{$\begin{array}{c}\text { Strains contain aer } A \text { and } \\
\text { ahh1 genes }\end{array}$} \\
\hline & 48 & 19.2 & 19 & 39.5 & 2 & 10.5 \\
\hline
\end{tabular}

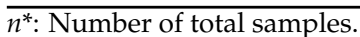




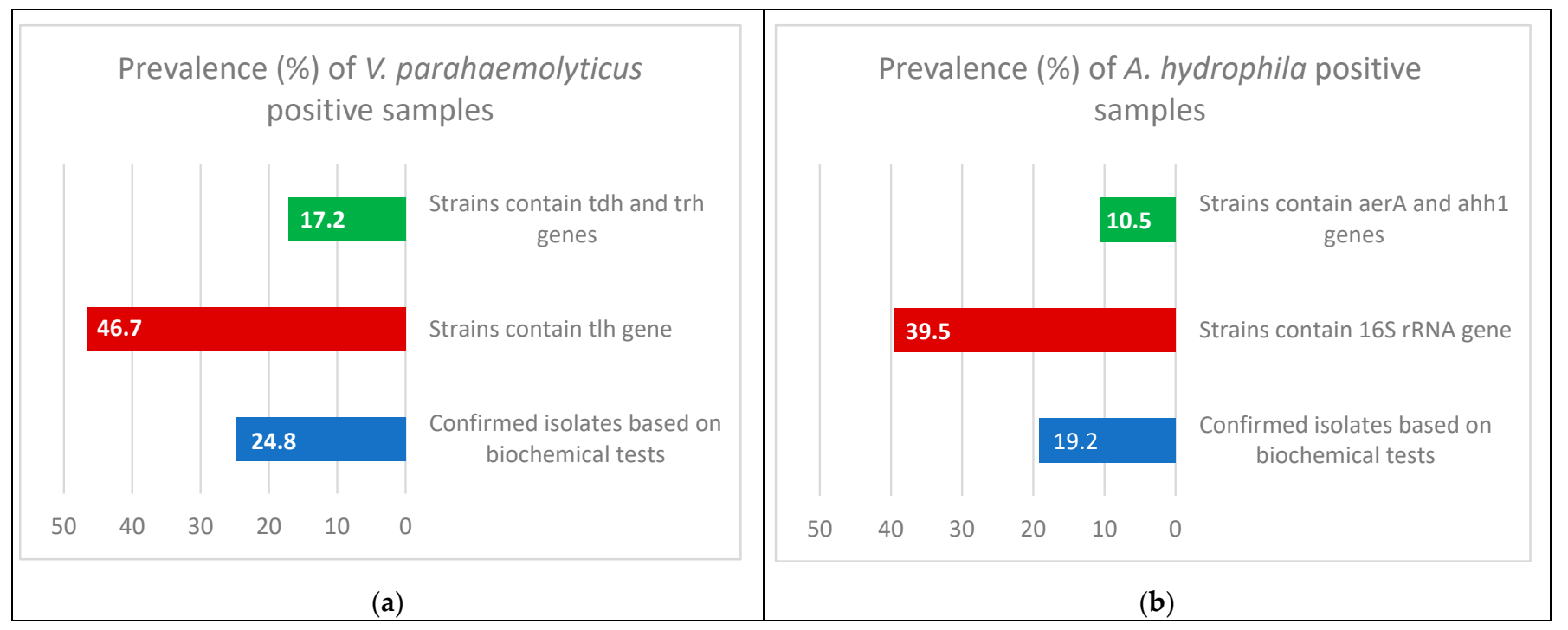

Figure 2. Prevalence and molecular identification of confirmed isolates of V. parahaemolyticus (a) and A. hydrophila (b) in Nile tilapia.

\subsection{Molecular Identification:}

2.4.1. Molecular identification of V. parahaemolyticus

Multiplex PCR was performed on the V. parahaemolyticus isolates. It was found that only $29(46.7 \%)$ of the samples contained the thermolabile hemolysin (tlh) gene at $450 \mathrm{bp}$, and only $5(17.2 \%)$ of the 29 samples contained both the thermostable direct hemolysin (tdh) gene at $269 \mathrm{bp}$ and $t d h$-related hemolysin $(t r h)$ gene at $500 \mathrm{bp}$ (Table 1; Figures 2 and 3).

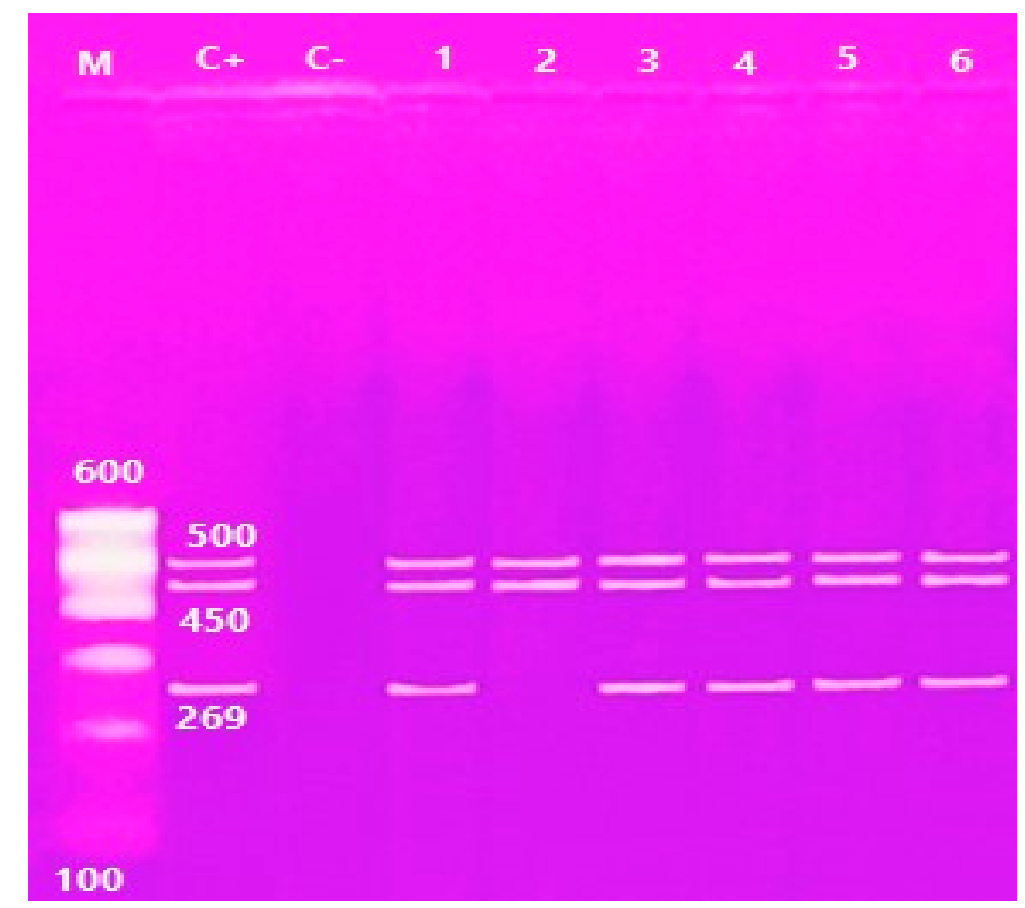

Figure 3. Agarose gel electrophoresis of multiplex PCR of trh (500 bp) th (450 bp) and tdh (269 bp) genes of $V$. parahaemolyticus. Lane M: 100 bp ladder, Lane C+: control positive, Lane C-: Control negative; Lanes 1, 2, 3, 4, 5 and 6: positive strains for trh genes; Lane 1, 2, 3, 4, 5 and 6: positive strains for th genes; Lanes 1, 3, 4, 5 and 6: positive strains for $t d h$ genes. 


\subsubsection{Molecular identification of $A$. hydrophila}

Multiplex PCR was done on the A. hydrophila isolates; to distinguish the presence of virulence genes, it was found that only 19 (39.5\%) samples contained the $16 \mathrm{~S} r R N A$ gene at $356 \mathrm{bp}$, and only $2(10.5 \%)$ from 19 samples contained the aerolysin (aer $A)$ gene at $309 \mathrm{bp}$ and extracellular hemolysin (ahh1) gene at $130 \mathrm{bp}$ (Table 1; Figures 2 and 4).

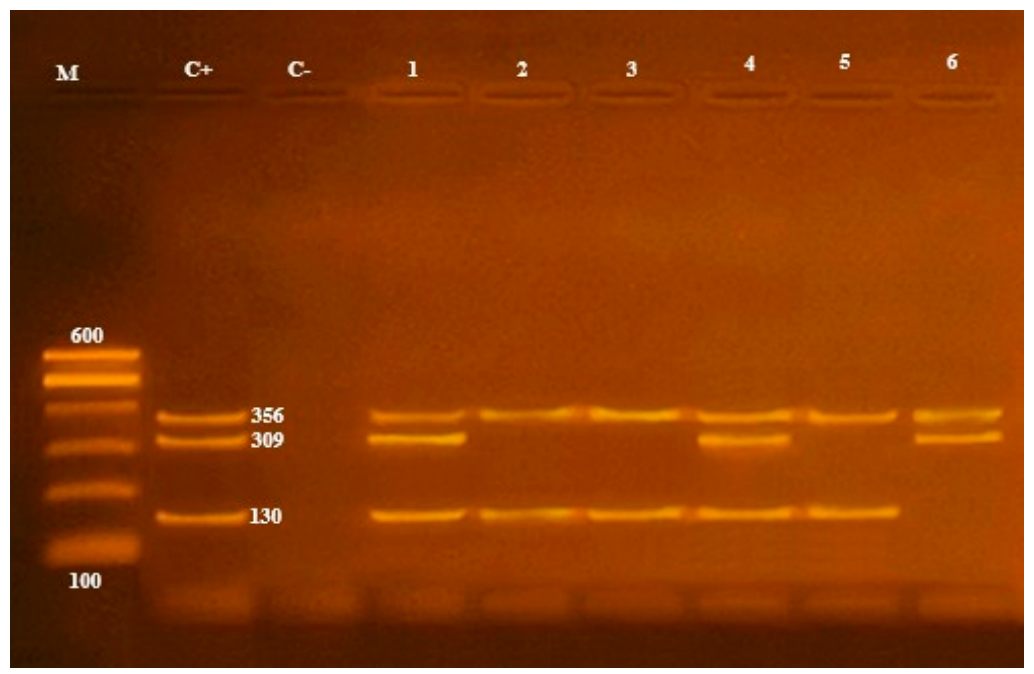

Figure 4. $16 S$ rRNA (356 bp), aerA (309 bp) and ahhl (130 bp) virulence genes to characterize $A$. hydrophila. Lane M: 100 bp ladder, Lane C+: control positive, Lane C-: control negative; Lanes 1, 2, 3, 4, 5 and 6: positive strains for $16 S$ rRNA genes; Lanes 1, 4 and 6: positive strains for aer $A$ genes; Lanes 1, 2, 3, 4 and 5: positive strains for ahhl genes.

2.5. Antibiotic Susceptibility of V. parahaemolyticus and A. hydrophila Positive Strains Confirmed by Multiplex PCR Assay

An antibiogram sensitivity test was performed on the 29 positive samples of the $V$. parahaemolyticus strains, which were confirmed by multiplex PCR. This indicated that $V$. parahaemolyticus was highly sensitive to ampicillin and amikacin (65.7\%). The intermediate was exhibited against neomycin $(48.4 \%)$, cefotaxime $(34.4 \%)$, sulfamethoxazole, tetracycline and ciprofloxacin $(31.0 \%)$. However, a higher resistance pattern varied among the other tested drugs; the highest resistance $(100 \%)$ was recorded for cloxacillin, streptomycin and erythromycin, followed by nalidixic acid (82.7\%) (Table 4; Figure 5). On the other hand, $A$. hydrophila strains were highly sensitive to gentamycin $(84.2 \%)$, tetracycline, ciprofloxacin $(68.4 \%)$, amikacin, neomycin and kanamycin $(52.6 \%)$, and demonstrated high resistance to cloxacillin and erythromycin (100\%), followed by cefotaxime and streptomycin $(84.2 \%)$, nalidixic acid, sulfamethoxazole and cephalothin (68.4\%) (Table 2; Figure 6).

Table 2. Antibiotic susceptibility of V. parahaemolyticus $(n=29)$ and A. hydrophila $(n=19)$.

\begin{tabular}{|c|c|c|c|c|c|c|c|c|c|c|c|c|}
\hline \multirow{3}{*}{ Antimicrobial Agent } & \multicolumn{6}{|c|}{ V. parahaemolyticus } & \multicolumn{6}{|c|}{ A. hydrophila } \\
\hline & \multicolumn{2}{|c|}{ Sensitive } & \multicolumn{2}{|c|}{ Intermediate } & \multicolumn{2}{|c|}{ Resistant } & \multicolumn{2}{|c|}{ Sensitive } & \multicolumn{2}{|c|}{ Intermediate } & \multicolumn{2}{|c|}{ Resistant } \\
\hline & $n$ & $\%$ & $n$ & $\%$ & $n$ & $\%$ & $n$ & $\%$ & $n$ & $\%$ & $n$ & $\%$ \\
\hline Streptomycin & 0 & 0 & 0 & 0 & 29 & 100 & 0 & 0 & 3 & 15.8 & 16 & 84.2 \\
\hline Erythromycin & 0 & 0 & 0 & 0 & 29 & 100 & 0 & 0 & 0 & 0 & 19 & 100 \\
\hline Cloxacillin & 0 & 0 & 0 & 0 & 29 & 100 & 0 & 0 & 0 & 0 & 19 & 100 \\
\hline Nalidixic Acid & 0 & 0 & 5 & 16.7 & 24 & 82.7 & 3 & 15.8 & 3 & 15.8 & 13 & 68.4 \\
\hline Cefotaxime & 0 & 0 & 10 & 34.4 & 19 & 65.5 & 0 & 0 & 0 & 0 & 16 & 84.2 \\
\hline Sulfamethoxazole & 5 & 17.2 & 9 & 31.0 & 15 & 51.7 & 6 & 31.6 & 0 & 0 & 13 & 68.4 \\
\hline Neomycin & 0 & 0 & 14 & 48.3 & 15 & 51.7 & 10 & 52.6 & 3 & 15.8 & 6 & 31.6 \\
\hline
\end{tabular}


Table 2. Cont

\begin{tabular}{|c|c|c|c|c|c|c|c|c|c|c|c|c|}
\hline \multirow{3}{*}{ Antimicrobial Agent } & \multicolumn{6}{|c|}{ V.parahaemolyticus } & \multicolumn{6}{|c|}{ A. hydrophila } \\
\hline & \multicolumn{2}{|c|}{ Sensitive } & \multicolumn{2}{|c|}{ Intermediate } & \multicolumn{2}{|c|}{ Resistant } & \multicolumn{2}{|c|}{ Sensitive } & \multicolumn{2}{|c|}{ Intermediate } & \multicolumn{2}{|c|}{ Resistant } \\
\hline & $n$ & $\%$ & $n$ & $\%$ & $n$ & $\%$ & $n$ & $\%$ & $n$ & $\%$ & $n$ & $\%$ \\
\hline Tetracycline & 5 & 17.2 & 9 & 31.0 & 15 & 51.7 & 13 & 68.4 & 0 & 0 & 6 & 31.6 \\
\hline Cephalothin & 9 & 31.0 & 5 & 17.2 & 15 & 51.7 & 3 & 15.8 & 3 & 15.8 & 13 & 68.4 \\
\hline Kanamycin & 14 & 48.3 & 0 & 0 & 15 & 51.7 & 9 & 47.4 & 0 & 0 & 10 & 52.6 \\
\hline Ciprofloxacin & 9 & 31.0 & 9 & 31.0 & 11 & 37.9 & 13 & 68.4 & 3 & 15.8 & 3 & 15.8 \\
\hline Gentamicin & 15 & 51.7 & 5 & 17.2 & 9 & 31.0 & 16 & 84.2 & 0 & 0 & 3 & 15.8 \\
\hline Ampicillin & 19 & 65.5 & 0 & 0 & 10 & 34.5 & 3 & 15.8 & 6 & 31.6 & 10 & 52.6 \\
\hline Amikacin & 19 & 65.7 & 5 & 17.2 & 5 & 17.2 & 10 & 52.6 & 3 & 15.8 & 6 & 31.6 \\
\hline
\end{tabular}

$n$ : Number of tested positive bacterial strains confirmed by multiplex PCR assay.

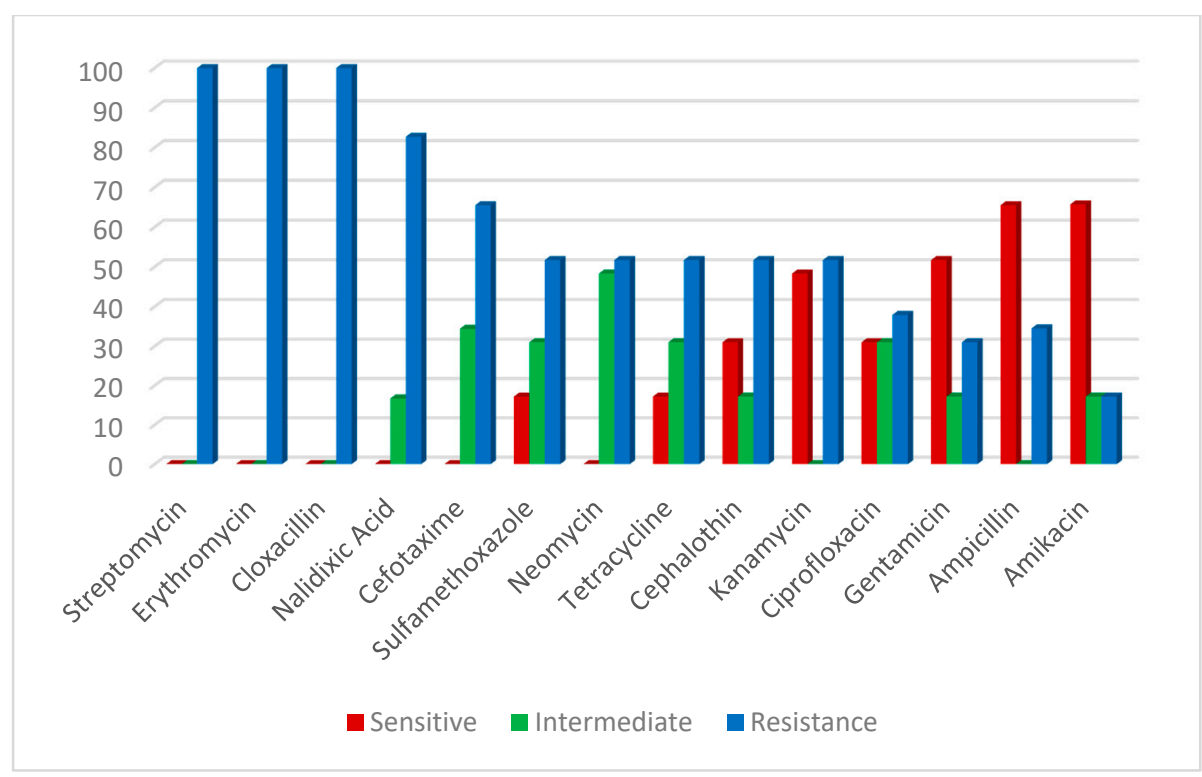

Figure 5. Antibiotic susceptibility of V. parahaemolyticus.

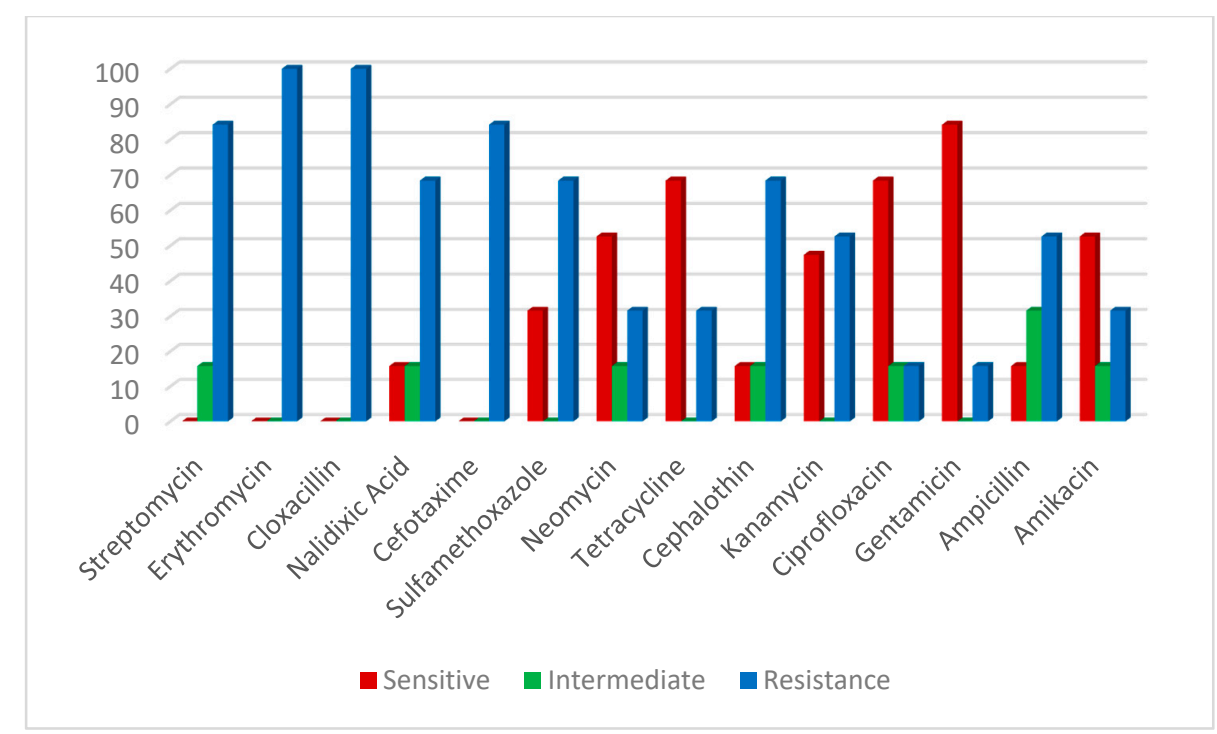

Figure 6. Antibiotic susceptibility of A. hydrophila. 
The MAR index values showed multiple resistant patterns, revealing that the MAR index averages of $V$. parahaemolyticus and A. hydrophila were 0.587 (Table 3) and 0.586 (Table 4), respectively.

Table 3. Antibiotics resistance profile and MAR index of $V$. parahaemolyticus isolated from Nile tilapia $\left(n^{*}=29\right)$.

\begin{tabular}{ccc}
\hline $\begin{array}{c}\text { No. of Tested } \boldsymbol{V} \text {. } \\
\text { parahaemolyticus Strains }\end{array}$ & Antimicrobial Resistance Profile & $\begin{array}{c}\text { MAR } \\
\text { Index }\end{array}$ \\
\hline 5 & $\mathrm{~S}, \mathrm{E}, \mathrm{CL}, \mathrm{NA}, \mathrm{CF}, \mathrm{SXT}, \mathrm{N}, \mathrm{T}, \mathrm{CN}, \mathrm{K}, \mathrm{CP}, \mathrm{G}, \mathrm{AM}, \mathrm{AK}$ & 1 \\
\hline 4 & $\mathrm{~S}, \mathrm{E}, \mathrm{CL}, \mathrm{NA}, \mathrm{CF}, \mathrm{SXT}, \mathrm{N}, \mathrm{T}, \mathrm{CN}, \mathrm{K}, \mathrm{CP}, \mathrm{G}, \mathrm{AM}$ & 0.928 \\
\hline 1 & $\mathrm{~S}, \mathrm{E}, \mathrm{CL}, \mathrm{NA}, \mathrm{CF}, \mathrm{SXT}, \mathrm{N}, \mathrm{T}, \mathrm{CN}, \mathrm{K}, \mathrm{CP}, \mathrm{AM}$ & 0.857 \\
\hline 1 & $\mathrm{~S}, \mathrm{E}, \mathrm{CL}, \mathrm{NA}, \mathrm{CF}, \mathrm{SXT}, \mathrm{N}, \mathrm{T}, \mathrm{CN}, \mathrm{K}, \mathrm{CP}$ & 0.785 \\
\hline 4 & $\mathrm{~S}, \mathrm{E}, \mathrm{CL}, \mathrm{NA}, \mathrm{CF}, \mathrm{SXT}, \mathrm{N}, \mathrm{T}, \mathrm{CN}, \mathrm{K}$ & 0.714 \\
\hline 4 & $\mathrm{~S}, \mathrm{E}, \mathrm{CL}, \mathrm{NA}, \mathrm{CF}$ & 0.357 \\
\hline 5 & $\mathrm{~S}, \mathrm{E}, \mathrm{CL}, \mathrm{NA}$ & 0.285 \\
\hline 4 & $\mathrm{~S}, \mathrm{E}, \mathrm{CL}$ & 0.21 \\
\hline 1 & $\mathrm{~S}, \mathrm{E}$ & 0.142 \\
\hline & & 0.587 \\
\hline$n^{*}:$ total number of V. parahaemolyticus positive samples confirmed by multiplex PCR assay.
\end{tabular}

Table 4. Antibiotic resistance profile and MAR index of $A$. hydrophila isolated from Nile tilapia $\left(n^{*}=19\right)$.

\begin{tabular}{ccc}
\hline $\begin{array}{c}\text { No. of Tested } \boldsymbol{A} . \\
\text { hydrophila } \text { Strains }\end{array}$ & Antimicrobial Resistance Profile & MAR Index \\
\hline 3 & $\mathrm{E}, \mathrm{CL}, \mathrm{S}, \mathrm{CF}, \mathrm{NA}, \mathrm{SXT}, \mathrm{CN}, \mathrm{K}, \mathrm{AM}, n, \mathrm{~T}, \mathrm{AK}, \mathrm{CP}, \mathrm{G}$ & 1 \\
\hline 3 & $\mathrm{E}, \mathrm{CL}, \mathrm{S}, \mathrm{CF}, \mathrm{NA}, \mathrm{SXT}, \mathrm{CN}, \mathrm{K}, \mathrm{AM}, \mathrm{N}, \mathrm{T}, \mathrm{AK}$ & 0.857 \\
\hline 4 & $\mathrm{E}, \mathrm{CL}, \mathrm{S}, \mathrm{CF}, \mathrm{NA}, \mathrm{SXT}, \mathrm{CN}, \mathrm{K}, \mathrm{AM}$ & 0.642 \\
\hline 3 & $\mathrm{E}, \mathrm{CL}, \mathrm{S}, \mathrm{CF}, \mathrm{NA}, \mathrm{SXT}, \mathrm{CN}$ & 0.5 \\
\hline 3 & $\mathrm{E}, \mathrm{CL}, \mathrm{S}, \mathrm{CF}$ & 0.285 \\
\hline 3 & $\mathrm{E}, \mathrm{CL}$ & 0.214 \\
\hline & & 0.586 \\
\hline$n^{*}:$ total number of A. hydrophila positive samples confirmed by multiplex PCR assay.
\end{tabular}

\section{Discussion}

Hadous drainage is the primary water supply for Manzala fish farm, but unfortunately, it is contaminated by agricultural and industrial activities, especially during rice cultivation in the summer due to the use of many chemicals, and during canal cleaning in the winter. Both factors contribute to the pollution of Hadous water sources, putting fish and their development under stress [39].

Another issue is the abundance of Eichhornia spp., which consumes large quantities of water containing all the nutrients needed for fish production, leaving the water devoid of basic plankton species. When these plants die, they decay, producing toxic gasses such as hydrogen disulfide, as well as some trace elements like copper, iron, phosphorus, manganese, and nitrogenous compounds, that increase stress on the fish in this farm. Finally, the fluctuating water level of Hadous drainage throughout the year reflects Manzala fish-farm water level, contributing to a reduction in the water quality and increasing stress on the fish in this farm [40].

As a result of the length of the breeding period (about 18 months) and the increase in the organic matter at the bottom of the pond, there has been a severe decrease in dissolved oxygen in the water, with an increase in the $\mathrm{pH}$ and toxic ammonia in the water that plays important roles in the multiplication of pathogens leading to diseases of fishes [41-43]. 
Typical signs of septicemia, such as deep dermal ulceration, abdominal dropsy, skin roughness, skin abrasion and protruded hemorrhagic anal opening, have been shown in the diseased tilapia according to the current research. Postmortem lesions have also been evident. Furthermore, spleen and liver congestion have been determined. These results are in agreement with the previously reported work $[44,45]$.

The prevalence of Vibrio was detected by [46] who reported a lower incidence of Vibrio spp. in cultured Nile tilapia (16.48 \%) and a higher prevalence of $98.67 \%$ in freshwater fish [47]. However, other studies reported a comparable prevalence to this study, for example, a lower prevalence of $A$. hydrophila (13.2\%) in the isolated Nile tilapia [48] and as the most prevalent bacterial pathogens (43\%) in Nile tilapia in Uganda [49].

An MAR index above 0.2 is a parameter used to reveal the spread of bacterial resistance in certain population. An MAR index more than 0.2 reveals that the strains of such bacteria originated from a habitat in which different antibiotics are used and the abuse of antibiotics in aquatic and environmental systems [50,51]. A high incidence of MAR is permitted by genetic exchange between MAR pathogens and other bacteria [38]. In this study, the MAR indices of $V$. parahaemolyticus and A. hydrophila isolates were 0.587 and 0.586, respectively, revealing that these isolates were derived from samples from high-risk sources [52]. This is not surprising because the V. parahaemolyticus has shown $100 \%$ resistance to tested antibiotics in this research such as streptomycin, erythromycin and cloxacillin. This finding corroborates the ideas of various researchers [52-56] who discovered that several $V$. parahaemolyticus isolates from seafood are resistant to multiple antibiotics. Another study [56] reported that $V$. parahaemolyticus recovered from commonly consumed aquatic products in Shanghai was $75.4 \%$ resistant to streptomycin. In contrast, the A. hydrophila isolates showed multiple resistance to erythromycin, cloxacillin (100\%), streptomycin and cefotaxime (84\%). These findings are consistent with a past study [57], which found $A$. hydrophila isolates from red hybrid tilapia in Malaysia were multidrug resistant to cefotaxime, sulfamethoxazole, erythromycin and streptomycin, with an MAR index of 0.5. Similarly, one study [58] found that the MAR index of $A$. hydrophila was between 0.12 to 0.59 and another study [59] found that the MAR index was between 0.243 and 0.457 for Aeromonads isolated from decorative fish farming systems. At the same time, gentamycin was reported as the most active drug against $A$. hydrophila (84\%), followed by tetracycline and ciprofloxacin (68.4\%); this result is inconsistent with previous findings [60], which reported the lowest sensitivity to gentamycin (40\%) and high resistance to chloramphenicol and ciprofloxacin ( $72 \%$ and $48 \%$, respectively). Another study reported that $A$. hydrophila was highly sensitive to ciprofloxacin and resistant to tetracycline [61]. In contrast, $V$. parahaemolyticus was sensitive to ampicillin, but these results disagree with those [62] to have shown that reduced resistance to ampicillin is only found in V. parahaemolyticus. Differences in sample sources can be explained by changes in the MAR index [63,64]; antibiotic resistance levels are subject to various selective pressures due to geographic spread [52] and methodologies [65].

The use of antimicrobials in aquaculture, could impose an impact on the development of resistance in human health known as a direct spread of resistance from aquatic environments to human. Similarly, increasing microbial resistance problems could spread from country to another, for instant, the export/import of foods like fish and fishery products [51].

The risk of $V$. parahaemolyticus in seafood to human health was determined by detecting the microorganisms, followed by PCR-based detection of the genes that generate the $t d h$ and trh toxins. About 2.5 percent of 120 seafood samples tested positive for one or both virulent genes $t d h$ and $t r h$, according to another major study [66]. Although one study found that shellfish samples tested in Chile were more likely to be positive for $t d h$, with 85 percent $(17 / 20)$ of overall tested samples being positive [67]. Furthermore, the $t d h$ and trh genes were found in 8.16 and $12.24 \%$ of fish samples South China, respectively [68]. One study [69] contradicts our results; they approved the occurrence of V. parahaemolyticus based on PCR with a lower frequency than ours, and about $3 \%$ of collected seafood samples 
were positive for $t d h$ and $t r h$ virulence genes. Other studies were conducted $[70,71]$ that approved the occurrence of $V$. parahaemolyticus at higher frequencies. Various researchers isolated V. parahaemolyticus from Thai shrimp samples and discovered that these isolates lacked the $t d h$ and trh virulence genes [72-74].

Manzala Lake is furious with nutrients such as calcium, magnesium, and chlorides; that are closely related to the number of Aeromonas spp. found in brackish water [40]. A. hydrophila has gained increased attention because of its pathogenicity to humans and the widespread prevalence of the organism in the environment, food and water [75]. Traditional microbiological procedures of Aeromonas spp. from food samples are time consuming. The polymerase chain reaction technique has been developed to solve these problems [76,77], and the incidence of $A$. hydrophila isolated from tilapia investigated. It secretes multiple virulence parameters, such as aerolysin and $\alpha$-hemolysin [78]. The detection of the $16 S$ $r R N A$ gene has contributed to the rapid and accurate characterization of the bacteria [22]. In addition to biochemical tests, the $16 S r R N A$ gene is an essential tool in diagnostic laboratories for recognizing microbes [79]. In this regard, approximately $39.5 \%$ of these isolates were positive for the $16 \mathrm{sr} R N A$ gene and $10.5 \%$ were positive for the aer $A$ and ahh1 genes. In addition, the aer $A$ and ahh1 virulence genes were present in $A$. hydrophila, which was confirmed by applying PCR with a prevalence of approximately $52.6 \%$ [80]. Wang et al. performed multiplex PCR for the recognition of the aerA and ahh1 genes in A. hydrophila and $A$. sobria [77]. The virulence range of aeromonads may originate from variations in the genotypes and phenotypes that are found in the environment. The A. hydrophila $\beta$-hemolysin virulence gene has been isolated from freshwater fish in China [81]. Cloned $\beta$-hemolysin sequences have been used to detect pathogenic $A$. hydrophila strains [82]. Our findings are consistent with past research [83], which detected the presence of the aerA gene in $85 \%$ of pathogenic $A$. hydrophila isolates from fish and pond water, which caused hemolysis of red blood cells, leading to hemorrhagic signs on fish skin and internal organs due to the presence of hemolysin and enterotoxigenic properties [75,84]. A negative PCR result does not prove the absence of the virulence gene, but may result from sequence differences in the primer binding sites [85]. These findings indicate the importance of performing biological tests for determining the virulence factors of some strains and identifying the potential pathogenicity of $A$. hydrophila due to their possible public health risks [86]. [37] detected the prevalence of $a h h 1$ and aer $A$ virulence factors with $28 \%$ and $68 \%$ frequencies of $A$. hydrophila isolated from fish collected from Damietta governorate in Egypt. The hemolysin gene was detected in our study with a percentage that is lower than that reported in previous studies (30-100\%) [87], while the aerolysin gene was identified with a frequency of $68 \%$ of the isolates, which is lower than the detected rates that ranged from $70 \%$ to $100 \%$ in other studies [88,89]. However, another study reported a lower rate of $66.7 \%$ [90]. For instance, in another study, the prevalence of the aerA gene was high (83.3\%) and that of the $a h h 1$ gene was low (16.7\%) [91].

\section{Materials and Methods}

\subsection{Farm Information}

Manzala lake is an important Egyptian lake according to its size and economic value [42]. The study area (Manzala fish-farm) includes fifty two ponds in four sections each consists of thirteen acres, so the total water area production equal about six hundred seventy six acre. The main water source of this farm is Hadous drainage, that is considered as the main drainage to Manzala Lake ( $49 \%$ of the drainage from the eastern delta). This farm is representative of the thousands of farms in Egypt. The volume of production of this farm is about 1400 tons/year. 


\subsection{Fish Sampling}

Specimens (n. 250) of Nile tilapia fish were collected from five ponds with constant environment parameters in all ponds for two weeks.

The fish (Age of fish $=15$ months, Length of fish $=15 \mathrm{~cm}$, Weigh of fish = 200-250 gm) collected from the pond had a breeding time of around 18 months with high organic matter at the bottom of the pond, and low dissolved oxygen and high $\mathrm{pH}$ and toxic ammonia in the water. The mortality rate was about $10 \%$.

The experiments were done according to the Research Ethics Committee of the Faculty of Veterinary Medicine, Mansoura. The samples were collected in sterilized sealed plastic containers, transported to the laboratory in a cold box below $4{ }^{\circ} \mathrm{C}$, and analyzed immediately [92].

\subsection{Bacteriological Examination \\ 4.3.1. Preparation of Fish Samples}

Five grams of individual fish muscle, under aseptic conditions, was homogenized into $45 \mathrm{~mL}$ of $3 \% \mathrm{NaCl}$ plus $1 \%$ alkaline peptone water for $V$. parahaemolyticus enrichment and tryptic soya broth for A. enrichment [93], followed by incubation at $37^{\circ} \mathrm{C}$ for $18 \mathrm{~h}$. for $V$. parahaemolyticus and at $37^{\circ} \mathrm{C}$ for $24 \mathrm{~h}$. for $A$. hydrophila [94].

\subsubsection{Culture Characters}

A loop of prepared fish samples was inoculated with TCBS agar was then incubated at $37^{\circ} \mathrm{C}$ for $18-24 \mathrm{~h}$ [95]. The isolated colonies appeared as green or blue-green colonies (sucrose negative) according to the power to ferment sucrose [96]. Suspected colonies were collected and transferred onto a tryptic soya agar slant enriched with $2 \% \mathrm{NaCl}$ for further microscopic and biochemical identification. For the isolation of $A$. hydrophila, Aeromonas agar base medium (Rayan) supplemented with ampicillin $(5 \mathrm{mg} / \mathrm{L})$ (Oxoid) was used. A loopful from previously incubated enriched samples of fish was inoculated on an Aeromonas agar base containing ampicillin (Oxoid) and incubated at $37^{\circ} \mathrm{C}$ for $18-24 \mathrm{~h}$. The isolated colonies appeared green with black centers. Suspected colonies were picked and transferred onto tryptic soya agar slants for further microscopic and biochemical identification [97].

\subsubsection{Biochemical Examination}

Biochemical identification of bacterial isolates was performed using the method described in Bergey's Manual ${ }^{\circledR}$ of Systematic Bacteriology [98].

The biochemical tests used were cytochrome-oxidase (Oxoid, Denver, USA), catalase (Al-Goumhoria Co, Cairo, Egypt), oxidation-fermentation medium (O-F) (BioMérieux, Marcy-l'Étoile, France), glucose gas production and indole tests (Al-Goumhoria Co, Cairo, Egypt), Esculin hydrolysis (bile esculin agar medium (DifcoTM, California, USA), VogesProskauer tests, arabinose, sucrose, lactose and mannose acid production, lysine decarboxylase and arginine dihydrolase and reduction of nitrates. Further identification was achieved using an analytical profile index (API 20 E system (BioMérieux, Paris, France), as instructed by the manufacturer.

\subsection{Antimicrobial Susceptibility Testing and MAR Index Value}

To verify the sensitivity of the test, 14 antimicrobials were used (Table 5). The single diffusion method was used to evaluate the antimicrobial susceptibility according to [99] for V. parahaemolyticus and [100] for A. hydrophila, and the results were applied according to [101]. The multiple antibiotic resistance (MAR) index for each strain was done according to the equation stipulated by $[83,102,103]$ as follows: MAR index $=$ number of resistance/total number of antibiotic. 
Table 5. Antimicrobial discs used for $V$. parahaemolyticus and A. hydrophila.

\begin{tabular}{ccc}
\hline Antibiotic & Symbol & Concentration \\
\hline Streptomycin & $\mathrm{S}$ & $10 \mu \mathrm{g}$ \\
\hline Erythromycin & $\mathrm{E}$ & $15 \mu \mathrm{g}$ \\
\hline Cloxacillin & $\mathrm{CL}$ & $5 \mu \mathrm{g}$ \\
\hline Nalidixic acid & $\mathrm{NA}$ & $30 \mu \mathrm{g}$ \\
\hline Cefotaxime & $\mathrm{CF}$ & $30 \mu \mathrm{g}$ \\
\hline Sulfamethoxazole & SXT & $25 \mu \mathrm{g}$ \\
\hline Neomycin & $\mathrm{N}$ & $30 \mu \mathrm{g}$ \\
\hline Tetracycline & $\mathrm{T}$ & $30 \mu \mathrm{g}$ \\
\hline Cephalothin & $\mathrm{CN}$ & $30 \mu \mathrm{g}$ \\
\hline Kanamycin & $\mathrm{K}$ & $30 \mu \mathrm{g}$ \\
\hline Ciprofloxacin & $\mathrm{CP}$ & $5 \mu \mathrm{g}$ \\
\hline Gentamycin & $\mathrm{G}$ & $10 \mu \mathrm{g}$ \\
\hline Ampicillin & AM & $10 \mu \mathrm{g}$ \\
\hline Amikacin & AK & $25 \mu \mathrm{g}$ \\
\hline
\end{tabular}

4.5. Molecular Identification of V. parahaemolyticus and A. hydrophila Virulence Genes

4.5.1. Molecular Identification of $A$. hydrophila Virulence Genes

Genomic DNA was extracted from A. hydrophila isolates using a DNA extraction kit (DNeasy kit, Qiagen, USA) following the manufacturer's guidelines. Multiplex PCR was performed to detect virulence factors including $16 S$ rRNA, aerA and ahh1 of the $A$. hydrophila isolate. The primer sequences and PCR products are illustrated in Table 6. Each PCR reaction was performed in a total volume of $25 \mu \mathrm{L}$ containing $12.5 \mu \mathrm{L}$ of dreamTaq master mix (Green PCR Master Mix (2X), Thermo Scientific), $1 \mu \mathrm{L}$ of each primer and $5 \mu \mathrm{L}$ of DNA template, and the total volume was completed to $25 \mu \mathrm{L}$ using DNase/RNase-free water. The PCR thermal conditions are illustrated in Table 6 . The first step was denaturation at $94{ }^{\circ} \mathrm{C}$ for $4 \mathrm{~min}$, followed by 35 cycles of denaturation at $94{ }^{\circ} \mathrm{C}$ for $30 \mathrm{~s}$, annealing for $30 \mathrm{~s}$ at the specified temperature according to each gene $\left(57^{\circ} \mathrm{C}\right.$ for $t h, t d h$ and $t r h ; 59^{\circ} \mathrm{C}$ for $16 \mathrm{~S}$ rRNA, ahh1 and aerA) and an extension step at $72{ }^{\circ} \mathrm{C}$ for $30 \mathrm{~s}$. After the end of the cycles, a final extension step at $72{ }^{\circ} \mathrm{C}$ for $10 \mathrm{~min}$ was added. The integrity of the PCR products was checked by electrophoresis on $1.5 \%$ agarose gels and visualized with a UV trans-illuminator with a 100-bp DNA ladder (Invitrogen, San Jose, CA, USA), which was used as the size standard.

\subsubsection{Molecular Identification of V. parahaemolyticus Virulence Genes}

The amplification was done on a Thermal Cycler (Master Cycler, Eppendorf, Hamburg, Germany). PCR was done in a $25 \mathrm{~mL}$ volume consisting of $0.5 \mathrm{mg}$ of genomic DNA, $0.5 \mathrm{mM}$ of each of the oligonucleotide primers for $t l h, t d h$ and $t r h(1.25 \mathrm{~mL}$ of each of the primers from a $20 \mathrm{mM}$ stock suspension), $2.5 \mathrm{~mL}$ of a 10_PCR reaction buffer (500 mM Tris-Cl, pH $8.9,500 \mathrm{mM} \mathrm{KCl}$ and $25 \mathrm{mM} \mathrm{MgCl} 2), 0.5 \mathrm{~mL} 10 \mathrm{mM}$ dNTPs, 1.25 units Taq DNA polymerase and an appropriate volume of sterile MilliQ water. Amplification of the DNA segment was performed with the following temperature cycling parameters: initial denaturation at $95^{\circ} \mathrm{C}$ for $5 \mathrm{~min}$ followed by 30 cycles of amplification. Each cycle consisted of denaturation at $95^{\circ} \mathrm{C}$ for $1 \mathrm{~min}$, primer annealing at $58^{\circ} \mathrm{C}$ for $1 \mathrm{~min}$, primer extension at $72{ }^{\circ} \mathrm{C}$ for $1 \mathrm{~min}$ and a final extension at $72{ }^{\circ} \mathrm{C}$ for $10 \mathrm{~min}$. Of each amplified product, $10 \mu \mathrm{L}$ was separated in $1.5 \%$ agarose gel by electrophoresis. The gel was then stained with ethidium bromide $(0.5 \mathrm{mg} / \mathrm{mL})$ and visualized on a UV transilluminator. A $100 \mathrm{bp}$ plus DNA Ladder was used to determine the fragment sizes. 
Table 6. Primer sets for PCR amplification of the target genes specific for V. parahaemolyticus and A. hydrophila.

\begin{tabular}{|c|c|c|c|}
\hline Target Gene & Oligonucleotide Sequence $\left(5^{\prime} \rightarrow 3^{\prime}\right)$ & $\begin{array}{l}\text { Product } \\
\text { Size (bp) }\end{array}$ & References \\
\hline \multicolumn{4}{|c|}{ V. parahaemolyticus } \\
\hline tlh & $\begin{array}{c}\text { F-5'AAAGCGGATTATGCAGAAGCACTG-'3 } \\
\text { R-5' GCTACTTTCTAGCATTTTCTCTGC-'3 }\end{array}$ & 450 & \multirow{3}{*}{ [104] } \\
\hline$t d h$ & $\begin{array}{l}\text { F-5' GTAAAGGTCTCTGACTTTTGGAC }{ }^{\prime 3} \\
\text { R-5 } 5^{\prime} \text { TGGAATAGAACCTTCATCTTCACC }{ }^{\prime} 3\end{array}$ & 269 & \\
\hline trh & $\begin{array}{c}\text { F-5' TTGGCTTCGATATTTTCAGTATCT '3 } \\
\text { R-5' CATAACAAACATATGCCCATTTCCG '3 }\end{array}$ & 500 & \\
\hline \multicolumn{4}{|c|}{ A. hydrophila } \\
\hline $16 S r R N A$ & $\begin{array}{c}\text { F-5' GGGAGTGCCTTCGGGAATCAGA-'3 } \\
\text { R-5' TCACCGCAACATTCTGATTTG-'3 }\end{array}$ & 356 & \multirow{3}{*}{ [105] } \\
\hline aer $A$ & $\begin{array}{l}\text { F-5'CAAGAACAAGTTCAAGTGGCCA-'3 } \\
\text { R-5' ACGAAGGTGTGGTTCCAGT-' } 3\end{array}$ & 309 & \\
\hline$a h h 1$ & $\begin{array}{l}\text { F-5' GCCGAGCGCCCAGAAGGTGAGTT-'3 } \\
\text { R-5' GAGCGGCTGGATGCGGTTGT -'3 }\end{array}$ & 130 & \\
\hline
\end{tabular}

\section{Conclusions}

Aquaculture in Egypt continues to be a growing, vital and important high-protein, easily digestible and high-value production sector for livestock. However, disease outbreaks are a major problem in aquaculture. Environmentally transmitted bacterial pathogens in their hosts can result in single and combined co-infections that have significant economic impacts on the aquaculture of Egypt. Antibiotic-resistant V. parahaemolyticus and A. hydrophila isolates in seafood may pose a danger to human health, and according to this study, adequate control measures should be implemented to reduce the risk of contamination and avoid antibiotic resistance. This would reduce the risk of transferring antibiotic-resistant bacteria to the human population through fish products. Therefore, antibiotic susceptibility should be determined in broader studies. It is important to promote a focus on alternative non-antibiotic control strategies for bacterial infections in farmed fish. To fully comprehend bacterial effects on Egyptian fish and human health, characterization of the isolated bacteria, including pathogenicity studies, is important. Future research should also concentrate on the use of more accurate methods of bacterial identification in order to identify contaminated seafood.

Author Contributions: H.A.Z., M.I.N., B.M.H., M.M.E. (Mostafa M. Eraqi), A.S.A. and M.M.E. (Moustafa M. Elshaer) proposed the research concept, carried out the experimental model development, Nile tilapia sample collection, $V$. parahaemolyticus and A. hydrophila isolation and accomplished the antibiotic-resistant, biochemical, biological and molecular analyses. M.M.E. (Mostafa M. Eraqi) provided the study, data curation, statistical analysis, writing and critical review of the final manuscript, which contributed to the interpretation of the results, as well as reviews of and revisions to the manuscript. All authors read the final version of the manuscript and approved it for publishing.

Funding: This research received no external funding.

Institutional Review Board Statement: The study was conducted according to the guidelines of the Declaration of Helsinki, and approved by the Institutional Review Board (or Ethics Committee) of Mansoura University under protocol code R/73.

Informed Consent Statement: Not applicable.

Acknowledgments: We extend our sincere thanks and appreciation to Salah Moselly, the President of the General Authority for Fish Resources Development, for the convenience of sample collection. The authors would like to thank the Deanship of Scientific Research at Majmaah University, Kingdom of Saudi Arabia, for supporting this work under Project Number R-2021-130.

Conflicts of Interest: The authors declare no conflict of interest. 


\section{References}

1. Soliman, N.F.; Yacout, D.M.M. Aquaculture in Egypt: Status, constraints and potentials. Aquac. Int. 2016, $24,1201-1227$. [CrossRef]

2. Abdel-Ghany, H.M.; El-Sayed, A.F.M.; Ezzat, A.A.; Essa, M.A.; Helal, A.M. Dietary lipid sources affect cold tolerance of Nile tilapia (Oreochromis niloticus). J. Therm. Biol. 2019, 79, 50-55. [CrossRef]

3. Ayyat, M.S.; Ayyat, A.M.N.; Naiel, M.A.E.; Al-Sagheer, A.A. Reversal effects of some safe dietary supplements on lead contaminated diet induced impaired growth and associated parameters in Nile tilapia. Aquaculture 2020, 515, 734580. [CrossRef]

4. Casadei, E.; Albert, J. Food and Agriculture Organization of the United Nations. Encycl. Food Health 2015, 749-753. [CrossRef]

5. Iwamoto, M.; Ayers, T.; Mahon, B.E.; Swerdlow, D.L. Epidemiology of seafood-associated infections in the United States. Clin. Microbiol. Rev. 2010, 23, 399-411. [CrossRef] [PubMed]

6. Wang, W.; Li, M.; Li, Y. Intervention Strategies for Reducing Vibrio Parahaemolyticus in Seafood: A Review. J. Food Sci. 2015, 80, R10-R19. [CrossRef] [PubMed]

7. Pech, Z.G.H.; Chavez, M.R.C.; Reynoso, F.L. Pathogenic Bacteria in Oreochromis Niloticus Var. Stirling Tilapia Culture. Fish. Aquac. J. 2017, 8. [CrossRef]

8. Hernández-Macedo, M.L.; Barancelli, G.V.; Contreras-Castillo, C.J. Microbial deterioration of vacuum-packaged chilled beef cuts and techniques for microbiota detection and characterization: A review. Braz. J. Microbiol. 2011, 42, 1-11. [CrossRef] [PubMed]

9. Eissa, I.A.M.; El-Lamei, M.; Sherif, M.; Youssef, F.; Zaki, M.S.; Bakry, M. Detection of hemolysin gene and antibiogramme of Aeromonas veronii biovar sobria isolated from mass mortalities in cultured Nile Tilapia in El-Sharkia governorate, Egypt. Life Sci. J. 2015, 12, 85-89. [CrossRef]

10. Dong, H.T.; Techatanakitarnan, C.; Jindakittikul, P.; Thaiprayoon, A.; Taengphu, S.; Charoensapsri, W.; Khunrae, P.; Rattanarojpong, T.; Senapin, S. Aeromonas jandaei and Aeromonas veronii caused disease and mortality in Nile tilapia, Oreochromis niloticus (L.). J. Fish. Dis. 2017, 40, 1395-1403. [CrossRef] [PubMed]

11. Meyer, F.P. Aquaculture disease and health management. J. Anim. Sci. 1991, 69, 4201-4208. [CrossRef]

12. Jeney, Z.; Jeney, G. Recent achievements in studies on diseases of common carp (Cyprinus carpio L.). Aquaculture 1995, 129, 397-420. [CrossRef]

13. Ellis, A.E. Innate host defense mechanisms of fish against viruses and bacteria. Dev. Comp. Immunol. 2001, 25, 827-839. [CrossRef]

14. Samuelsen, O.B.; Nerland, A.H.; Jørgensen, T.; Schrøder, M.B.; Svåsand, T.; Bergh, Ø. Viral and bacterial diseases of Atlantic cod Gadus morhua, their prophylaxis and treatment: A review. Dis. Aquat. Organ. 2006, 71, 239-254. [CrossRef]

15. Bricknell, I.R.; Bron, J.E.; Bowden, T.J. Diseases of gadoid fish in cultivation: A review. ICES J. Mar. Sci. 2006, 63, 253-266. [CrossRef]

16. Sommerset, I.; Krossøy, B.; Biering, E.; Frost, P. Vaccines for fish in aquaculture. Expert Rev. Vaccines 2005, 4, 89-101. [CrossRef] [PubMed]

17. Lightner, D.V.; Redman, R.M. Shrimp diseases and current diagnostic methods. Aquaculture 1998, 164, 201-220. [CrossRef]

18. Shimohata, T.; Takahashi, A. Diarrhea induced by infection of Vibrio parahaemolyticus. J. Med. Investig. 2010, 57, 179-182. [CrossRef]

19. Honda, T.; Iida, T. The pathogenicity of vibrio parahaemolyticus and the role of the thermostable direct haemolysin and related haemolysins. Rev. Med. Microbiol. 1993, 4, 106-113. [CrossRef]

20. Gutierrez West, C.K.; Klein, S.L.; Lovell, C.R. High frequency of virulence factor genes tdh, trh, and tlh in Vibrio parahaemolyticus strains isolated from a pristine estuary. Appl. Environ. Microbiol. 2013, 79, 2247-2252. [CrossRef] [PubMed]

21. Makino, K.; Oshima, K.; Kurokawa, K.; Yokoyama, K.; Uda, T.; Tagomori, K.; Iijima, Y.; Najima, M.; Nakano, M.; Yamashita, A.; et al. Genome sequence of Vibrio parahaemolyticus: A pathogenic mechanism distinct from that of V cholerae. Lancet 2003, 361, 743-749. [CrossRef]

22. Tang, J.; Zheng, A.; Bromfield, E.S.P.; Zhu, J.; Li, S.; Wang, S.; Deng, Q.; Li, P. 16S rRNA gene sequence analysis of halophilic and halotolerant bacteria isolated from a hypersaline pond in Sichuan, China. Ann. Microbiol. 2011, 61, 375-381. [CrossRef]

23. Pazhani, G.P.; Bhowmik, S.K.; Ghosh, S.; Guin, S.; Dutta, S.; Rajendran, K.; Saha, D.R.; Nandy, R.K.; Bhattacharya, M.K.; Mukhopadhyay, A.K.; et al. Trends in the Epidemiology of Pandemic and Non-pandemic Strains of Vibrio parahaemolyticus Isolated from Diarrheal Patients in Kolkata, India. PLoS Negl. Trop. Dis. 2014, 8, e2815. [CrossRef] [PubMed]

24. Di Pinto, A.; Ciccarese, G.; Tantillo, G.; Catalano, D.; Forte, V.T. A collagenase-targeted multiplex PCR assay for identification of Vibrio alginolyticus, Vibrio cholerae, and Vibrio parahaemolyticus. J. Food Prot. 2005, 68, 150-153. [CrossRef] [PubMed]

25. Gomez-Gil, B.; Roque, A. Isolation, Enumeration, and Preservation of the Vibrionaceae. Biol. Vibrios 2006, 13-26. [CrossRef]

26. El Deen, A.E.N.; Dorgham, S.M.; Hassan, A.H.M.; Hakim, A.S. Studies on Aeromonas hydrophila in Cultured Oreochromis niloticus at Kafr El Sheikh Governorate, Egypt with Reference to Histopathological Alterations in Some Vital Organs. World J. Fish. Mar. Sci. 2014, 6, 233-240. [CrossRef]

27. Martin-Carnahan, A.; Joseph, S.W. Aeromonadalesord. Nov. In Bergey's Manual@of Systematic Bacteriology: Volume Two the Proteobacteria Part B The Gammaproteobacteria; Brenner, D.J., Krieg, N.R., Staley, J.T., Garrity, G.M., Boone, D.R., De Vos, P., Goodfellow, M., Rainey, F.A., Schleifer, K.H., Eds.; Springer: Boston, MA, USA, 2005; pp. 556-587.

28. Demarta, A.; Küpfer, M.; Riegel, P.; Harf-Monteil, C.; Tonolla, M.; Peduzzi, R.; Monera, A.; José Saavedra, M.; Martínez-Murcia, A. Aeromonas tecta sp. nov., isolated from clinical and environmental sources. Syst. Appl. Microbiol. 2008, 31, 278-286. [CrossRef] [PubMed] 
29. Trakhna, F.; Harf-Monteil, C.; Abdelnour, A.; Maaroufi, A.; Gadonna-Widehem, P. Rapid Aeromonas hydrophila identification by TaqMan PCR assay: Comparison with a phenotypic method. Lett. Appl. Microbiol. 2009, 49, 186-190. [CrossRef]

30. Aboyadak, I.M.; Ali, N.G.; Goda, A.M.; Saad, W.; Salam, A.M. Non-Selectivity of R-S Media for Aeromonas hydrophila and TCBS Media for Vibrio Species Isolated from Diseased Oreochromis niloticus. J. Aquac. Res. Dev. 2017, 8, 1-5. [CrossRef]

31. Smith, P. Breakpoints for disc diffusion susceptibility testing of bacteria associated with fish diseases: A review of current practice. Aquaculture 2006, 261, 1113-1121. [CrossRef]

32. Salunke, G.; Namshikar, V.; Gaonkar, R.; Gaonkar, T. A case of Aeromonas hydrophila meningitis in septic shock. Trop. J. Med. Res. 2015, 18, 54. [CrossRef]

33. Chacón, M.R.; Figueras, M.J.; Castro-Escarpulli, G.; Soler, L.; Guarro, J. Distribution of virulence genes in clinical and environmental isolates of Aeromonas spp. Antonie Leeuwenhoek 2003, 84, 269-278. [CrossRef]

34. Kozaki, S.; Asao, T.; Kamata, Y.; Sakaguchi, G. Characterization of Aeromonas sobria hemolysin by use of monoclonal antibodies against Aeromonas hydrophila hemolysins. J. Clin. Microbiol. 1989, 27, 1782-1786. [CrossRef]

35. Soler, L.; Yáñez, M.A.; Chacon, M.R.; Aguilera-Arreola, M.G.; Catalán, V.; Figueras, M.J.; Martínez-Murcia, A.J. Phylogenetic analysis of the genus Aeromonas based on two housekeeping genes. Int. J. Syst. Evol. Microbiol. 2004, 54, 1511-1519. [CrossRef] [PubMed]

36. Devi, R.; Surendran, P.K.; Chakraborty, K. Antibiotic resistance and plasmid profiling of Vibrio parahaemolyticus isolated from shrimp farms along the southwest coast of India. World J. Microbiol. Biotechnol. 2009, 25, 2005-2012. [CrossRef]

37. Ahmed, H.A.; El Bayomi, R.M.; Hussein, M.A.; Khedr, M.H.E.; Abo Remela, E.M.; El-Ashram, A.M.M. Molecular characterization, antibiotic resistance pattern and biofilm formation of Vibrio parahaemolyticus and V. cholerae isolated from crustaceans and humans. Int. J. Food Microbiol. 2018, 274, 31-37. [CrossRef] [PubMed]

38. Krumperman, P.H. Multiple antibiotic resistance indexing of Escherichia coli to identify high-risk sources of fecal contamination of foods. Appl. Environ. Microbiol. 1983, 46, 165-170. [CrossRef]

39. El-Sheekh, M.M.; Deyab, M.A.I.; Desouki, S.S.; Eladl, M. Phytoplankton compositions as a response of water quality in el salam canal hadous drain and Damietta branch of river Nile Egypt. Pakistan J. Bot. 2010, 42, 2621-2633.

40. Zaky, M.M.M.; Mansour, F.A.; Persson, K.M. Factors influencing multi-drug resistant and plasmid DNA harbouring Aeromonas hydrophila isolated from Lake Manzala, Egypt. J. Bacteriol. Res. 2010, 2, 30-40.

41. Ahmed, M.H.; El Leithy, B.M.; Thompson, J.R.; Flower, R.J.; Ramdani, M.; Ayache, F.; Hassan, S.M. Application of remote sensing to site characterisation and environmental change analysis of North African coastal lagoons. Hydrobiologia 2009, 622, 147-171. [CrossRef]

42. Hamed, Y.A.; Abdelmoneim, T.S.; ElKiki, M.H.; Hassan, M.A.; Berndtsson, R. Assessment of heavy metals pollution and microbial contamination in water, sediments and fish of Lake Manzala, Egypt. Life Sci. J. 2013, 10, 86-99.

43. Moraes, F.R.; Martins, M.L. Favourable conditions and principal teleostean diseases in intensive fish farming. In Especial Topics in Tropical Intensive Freshwater Fish Farming; Cyrino, J.E.P., Urbinati, E.C., Fracalossi, D.M., Castagnolli, N., Eds.; Tec Art Publ.: Sao Paulo, Brazil, 2004; pp. 343-383.

44. Dahdouh, B.; Basha, O.; Khalil, S.; Tanekhy, M. Molecular Characterization, Antimicrobial Susceptibility and Salt Tolerance of Aeromonas hydrophila from Fresh, Brackish and Marine fishes. Alexandria J. Vet. Sci. 2016, 48, 46. [CrossRef]

45. Sarkar, M.J.A.; Rashid, M.M. Pathogenicity of the bacterial isolate Aeromonas hydrophila to catfishes, carps and perch. J. Bangladesh Agric. Univ. 2012, 10, 157-161. [CrossRef]

46. Hassan, S.; Abdel-Rahman, M.; Mansour, E.S.; Monir, W. Isolation, phenotypic characterization and antibiotic susceptibility of prevalent bacterial pathogens implicating the mortality of cultured Nile tilapia, Oreochromis niloticus. Egypt. J. Aquac. 2020, 10, 23-43. [CrossRef]

47. Noorlis, A.; Ghazali, F.M.; Cheah, Y.K.; Tuan Zainazor, T.C.; Ponniah, J.; Tunung, R.; Tang, J.Y.H.; Nishibuchi, M.; Nakaguchi, Y.; Son, R. Prevalence and quantification of Vibrio species and Vibrio parahaemolyticus in freshwater fish at hypermarket level. Int. Food Res. J. 2011, 18, 689-695.

48. Algammal, A.M.; Mohamed, M.F.; Tawfiek, B.A.; Hozzein, W.N.; Kazzaz, W.M.E.; Mabrok, M. Molecular typing, antibiogram and PCR-RFLP based detection of Aeromonas hydrophila complex isolated from Oreochromis niloticus. Pathogens 2020, 9, 238. [CrossRef] [PubMed]

49. Wamala, S.P.; Mugimba, K.K.; Mutoloki, S.; Evensen, O.; Mdegela, R.; Byarugaba, D.K.; Sørum, H. Occurrence and antibiotic susceptibility of fish bacteria isolated from Oreochromis niloticus (Nile tilapia) and Clarias gariepinus (African catfish) in Uganda. Fish. Aquat. Sci. 2018, 21, 1-10. [CrossRef]

50. Ehinmidu, J.O. Antibiotics susceptibility patterns of urine bacterial isolates in Zaria, Nigeria. Trop. J. Pharm. Res. 2003, 2, 223-228. [CrossRef]

51. Pokhrel, H.; Baishya, S.; Phukan, B.; Pillai, D.; Ashraf Rather, M. Occurrence and Distribution of Multiple Antibiotic Resistance Bacteria of Public Health Significance in Backwaters and Aquaculture Farm. Int. J. Curr. Microbiol. Appl. Sci. 2018, 7, 975-987. [CrossRef]

52. Lesley, M.B.; Velnetti, L.; Cheah, Y.K.; Son, R.; Kasing, A.; Samuel, L.; Micky, V.; Nishibuchi, M. Antibiotic resistance and plasmid profiling of Vibrio parahaemolyticus isolated from cockles (Anadara granosa) at Tanjung Karang, Kuala Selangor. Int. Food Res. J. 2011, 18. 
53. Manjusha, S.; Sarita, G.B. Plasmid associated antibiotic resistance in Vibrios isolated from coastal waters of Kerala. Int. Food Res. J. 2011, 18, 1171-1181.

54. Noorlis, A.; Ghazali, F.M.; Cheah, Y.K.; Tuan Zainazor, T.C.; Wong, W.C.; Tunung, R.; Pui, C.F.; Nishibuchi, M.; Nakaguchi, Y.; Son, R. Antibiotic resistance and biosafety of Vibrio cholerae and Vibrio parahaemolyticus from freshwater ish at retail level. Int. Food Res. J. 2011, 18, 1523-1530.

55. Odeyemi, O.A.; Stratev, D. Occurrence of antimicrobial resistant or pathogenic Vibrio parahaemolyticus in seafood. A mini review. Rev. Med. Vet. (Toulouse) 2016, 167, 93-98.

56. Su, C.; Chen, L. Virulence, resistance, and genetic diversity of Vibrio parahaemolyticus recovered from commonly consumed aquatic products in Shanghai, China. Mar. Pollut. Bull. 2020, 160, 111554. [CrossRef] [PubMed]

57. Pauzi, N.A.; Mohamad, N.; Azzam-Sayuti, M.; Yasin, I.S.M.; Saad, M.Z.; Nasruddin, N.S.; Azmai, M.N.A. Antibiotic susceptibility and pathogenicity of Aeromonas hydrophila isolated from red hybrid tilapia (Oreochromis niloticus $\times$ Oreochromis mossambicus) in Malaysia. Vet. World 2020, 13, 2166-2171. [CrossRef] [PubMed]

58. Jacobs, L.; Chenia, H.Y. Characterization of integrons and tetracycline resistance determinants in Aeromonas spp. isolated from South African aquaculture systems. Int. J. Food Microbiol. 2007, 114, 295-306. [CrossRef] [PubMed]

59. Sreedharan, K.; Philip, R.; Singh, I.S.B. Virulence potential and antibiotic susceptibility pattern of motile aeromonads associated with freshwater ornamental fish culture systems: A possible threat to public health. Brazilian J. Microbiol. 2012, 43, 754-765. [CrossRef]

60. Ahmed, H.A.; Mohamed, M.E.M.; Rezk, M.M.; Gharieb, R.M.A.; Abdel-Maksoud, S.A. Aeromonas hydrophila in fish and humans; prevalence, virulotyping and antimicrobial resistance. Slov. Vet. Res. 2018, 55, 113-124. [CrossRef]

61. Ashiru, A.W.; Uaboi-Egbeni, P.O.; Oguntowo, J.E.; Idika, C.N. Isolation and antibiotic profile of aeromonas species from tilapia fish (Tilapia nilotica) and catfish (Clarias betrachus). Pakistan J. Nutr. 2011, 10, 982-985. [CrossRef]

62. Lee, L.H.; Mutalib, N.S.A.; Law, J.W.F.; Wong, S.H.; Letchumanan, V. Discovery on antibiotic resistance patterns of Vibrio parahaemolyticus in Selangor reveals carbapenemase producing Vibrio parahaemolyticus in marine and freshwater fish. Front. Microbiol. 2018, 9, 1-13. [CrossRef] [PubMed]

63. Tunung, R.; Margaret, S.P.; Jeyaletchumi, P.; Chai, L.C.; Zainazor, T.C.T.; Ghazali, F.M.; Nakaguchi, Y.; Nishibuchi, M.; Son, R. Prevalence and quantification of Vibrio parahaemolyticus in raw salad vegetables at retail level. J. Microbiol. Biotechnol. 2010, 20, 391-396. [CrossRef]

64. Vincent, M.; Chan, C.S.W.; Apun, K. Molecular confirmation and characterization of Vibrio parahaemolyticus from retailed fish. Int. Food Res. J. 2015, 22, 1705-1710.

65. Robert-Pillot, A.; Guénolé, A.; Lesne, J.; Delesmont, R.; Fournier, J.M.; Quilici, M.L. Occurrence of the tdh and trh genes in Vibrio parahaemolyticus isolates from waters and raw shellfish collected in two French coastal areas and from seafood imported into France. Int. J. Food Microbiol. 2004, 91, 319-325. [CrossRef]

66. Lee, M.F.; Peng, C.F.; Lin, Y.H.; Lin, S.R.; Chen, Y.H. Molecular diversity of class 1 integrons in human isolates of Aeromonas spp. from southern Taiwan. Jpn. J. Infect. Dis. 2008, 61, 343-349.

67. Fuenzalida, L.; Armijo, L.; Zabala, B.; Hernández, C.; Rioseco, M.L.; Riquelme, C.; Espejo, R.T. Vibrio parahaemolyticus strains isolated during investigation of the summer 2006 seafood related diarrhea outbreaks in two regions of Chile. Int. J. Food Microbiol. 2007, 117, 270-275. [CrossRef] [PubMed]

68. Yang, Y.; Xie, J.; Li, H.; Tan, S.; Chen, Y.; Yu, H. Prevalence, antibiotic susceptibility and diversity of Vibrio parahaemolyticus isolates in seafood from South China. Front. Microbiol. 2017, 8, 1-9. [CrossRef] [PubMed]

69. Abd-Elghany, S.M.; Sallam, K.I. Occurrence and molecular identification of Vibrio parahaemolyticus in retail shellfish in Mansoura, Egypt. Food Control. 2013, 33, 399-405. [CrossRef]

70. Lu, S.; Liu, B.; Cao, J.; Zhou, B.; Levin, R. Incidence and enumeration of Vibrio parahaemolyticus in shellfish from two retail sources and the genetic diversity of isolates as determined by RAPD-PCR analysis. Food Biotechnol. 2006, 20, 193-209. [CrossRef]

71. Terzi, G.; Büyüktanir, Ö.; Yurdusev, N. Detection of the tdh and trh genes in Vibrio parahaemolyticus isolates in fish and mussels from Middle Black Sea Coast of Turkey. Lett. Appl. Microbiol. 2009, 49, 757-763. [CrossRef] [PubMed]

72. Singhapol, C.; Tinrat, S. Virulence Genes Analysis of Vibrio parahaemolyticus and Anti-vibrio Activity of the Citrus Extracts. Curr. Microbiol. 2020, 77, 1390-1398. [CrossRef]

73. Jones, J.L.; Lüdeke, C.H.M.; Bowers, J.C.; Garrett, N.; Fischer, M.; Parsons, M.B.; Bopp, C.A.; DePaola, A. Biochemical, serological, and virulence characterization of clinical and oyster Vibrio parahaemolyticus isolates. J. Clin. Microbiol. 2012, 50, $2343-2352$. [CrossRef] [PubMed]

74. Li, Y.; Xie, X.; Shi, X.; Lin, Y.; Qiu, Y.; Mou, J.; Chen, Q.; Lu, Y. Southern Coastal. Emerg. Infect. Dis. 2014, 20, $2012-2015$.

75. Arslan, S.; Küçüksari, R. Phenotypic and Genotypic Virulence Factors and Antimicrobial Resistance of Motile Aeromonas spp. from Fish and Ground Beef. J. Food Saf. 2015, 35, 551-559. [CrossRef]

76. Kingombe, C.I.B.; Huys, G.; Tonolla, M.; Albert, M.J.; Swings, J.; Peduzzi, R.; Jemmi, T. PCR detection, characterization, and distribution of virulence genes in Aeromonas spp. Appl. Environ. Microbiol. 1999, 65, 5293-5302. [CrossRef] [PubMed]

77. Wang, G.; Clark, C.G.; Liu, C.; Pucknell, C.; Munro, C.K.; Kruk, T.M.A.C.; Caldeira, R.; Woodward, D.L.; Rodgers, F.G. Detection and characterization of the hemolysin genes in Aeromonas hydrophila and Aeromonas sobria by multiplex PCR. J. Clin. Microbiol. 2003, 41, 1048-1054. [CrossRef] 
78. Howard, S.P.; Buckley, J.T. Activation of the hole-forming toxin aerolysin by extracellular processing. J. Bacteriol. 1985, 163, 336-340. [CrossRef]

79. Buller, N.B. Preparation of media for culture and identification. In Bacteria from Fish and Other Aquatic Animals: A Practical Identification Manual; CABI Publishing: Wallingford, UK, 2009; pp. 244-277. ISBN 9780851997384.

80. Yousr, A.H.; Napis, S.; Rusul, G.R.A.; Son, R. Detection of aerolysin and hemolysin genes in Aeromonas spp. isolated from environmental and shellfish sources by polymerase chain reaction. ASEAN Food J. 2007, 14, 115.

81. Xia, C.; Ma, Z.H.; Rahman, M.H.; Wu, Z.G. PCR cloning and identification of the $\beta$-haemolysin gene of Aeromonas hydrophila from freshwater fishes in China. Aquaculture 2004, 229, 45-53. [CrossRef]

82. Alperi, A.; Martínez-Murcia, A.J.; Ko, W.C.; Monera, A.; Saavedra, M.J.; Figueras, M.J. Aeromonas taiwanensis sp. nov. and Aeromonas sanarellii sp. nov., clinical species from Taiwan. Int. J. Syst. Evol. Microbiol. 2010, 60, 2048-2055. [CrossRef] [PubMed]

83. Singh, V.; Rathore, G.; Kapoor, D.; Mishra, B.N.; Lakra, W.S. Detection of aerolysin gene in Aeromonas hydrophila isolated from fish and pond water. Indian J. Microbiol. 2008, 48, 453-458. [CrossRef]

84. Tomás, J.M. The Main Aeromonas Pathogenic Factors. ISRN Microbiol. 2012, 2012, 1-22. [CrossRef]

85. Wong, C.Y.F.; Heuzenroeder, M.W.; Flower, R.L.P. Inactivation of two haemolytic toxin genes in Aeromonas hydrophila attenuates virulence in a suckling mouse model. Microbiology 1998, 144, 291-298. [CrossRef]

86. Hu, M.; Wang, N.; Pan, Z.H.; Lu, C.P.; Liu, Y.J. Identity and virulence properties of Aeromonas isolates from diseased fish, healthy controls and water environment in China. Lett. Appl. Microbiol. 2012, 55, 224-233. [CrossRef]

87. Bhowmik, P.; Bag, P.K.; Hajra, T.K.; De, R.; Sarkar, P.; Ramamurthy, T. Pathogenic potential of Aeromonas hydrophila isolated from surface waters in Kolkata, India. J. Med. Microbiol. 2009, 58, 1549-1558. [CrossRef] [PubMed]

88. Castro-Escarpulli, G.; Figueras, M.J.; Aguilera-Arreola, G.; Soler, L.; Fernández-Rendón, E.; Aparicio, G.O.; Guarro, J.; Chacón, M.R. Characterisation of Aeromonas spp. isolated from frozen fish intended for human consumption in Mexico. Int. J. Food Microbiol. 2003, 84, 41-49. [CrossRef]

89. Ye, Y.W.; Fan, T.F.; Li, H.; Lu, J.F.; Jiang, H.; Hu, W.; Jiang, Q.H. Characterization of Aeromonas hydrophila from hemorrhagic diseased freshwater fishes in Anhui Province, China. Int. Food Res. J. 2013, 20, 1449-1452.

90. Tahoun, A.B.M.B.; Ahmed, H.A.; Abou Elez, R.M.M.; El-Gedawy, A.A.; Elsohaby, I.; Abd El-Ghafar, A.E. Molecular characterisation, genotyping and survival of Aeromonas hydrophila isolated from milk, dairy products and humans in Egypt. Int. Dairy J. 2016, 63, 52-58. [CrossRef]

91. Salem, M.; Zahran, E.; Saad, R.; Zaki, V. Prevalence, molecular characterization, virulotyping, and antibiotic resistance of motile aeromonads isolated from Nile tilapia farms at northern Egypt. Mansoura Vet. Med. J. 2020, 21, 56-67. [CrossRef]

92. Xie, T.; Xu, X.; Wu, Q.; Zhang, J.; Cheng, J. Prevalence, molecular characterization, and antibiotic susceptibility of vibrio Parahaemolyticus from ready-to-eat foods in China. Front. Microbiol. 2016, 7, 1-10. [CrossRef]

93. Mzula, A.; Wambura, P.N.; Mdegela, R.H.; Shirima, G.M. Phenotypic and molecular detection of Aeromonads infection in farmed Nile tilapia in Southern highland and Northern Tanzania. Heliyon 2019, 5, e02220. [CrossRef] [PubMed]

94. Di Pinto, A.; Ciccarese, G.; De Corato, R.; Novello, L.; Terio, V. Detection of pathogenic Vibrio parahaemolyticus in southern Italian shellfish. Food Control 2008, 19, 1037-1041. [CrossRef]

95. Colakoglu, F.A.; Sarmasik, A.; Koseoglu, B. Occurrence of Vibrio spp. and Aeromonas spp. in shellfish harvested off Dardanelles cost of Turkey. Food Control 2006, 17, 648-652. [CrossRef]

96. Farmer, J.J.; Michael Janda, J.; Brenner, F.W.; Cameron, D.N.; Birkhead, K.M. Vibrio. In Bergey's Manual of Systematics of Archaea and Bacteria; Major Reference Works: London, UK, 2015; pp. 1-79. ISBN 9781118960608.

97. Ceylan, E.; Berktas, M.; Ağaoğlu, Z. The occurrence and antibiotic resistance of motile Aeromonas in livestock. Trop. Anim. Health Prod. 2009, 41, 199-204. [CrossRef]

98. Bergey, D.H.; Buchanan, R.E.; Gibbons, N.E. Bergey's Manual of Determinative Bacteriology; Williams \& Wilkins: Baltimore, MD, USA, 1974.

99. Adeyemi, A.; Enyinnia, V.; Nwanze, R.; Smith, S.; Omonigbehin, E. Antimicrobial susceptibilty of potentially pathogenic halophilic Vibrio species isolated from seafoods in Lagos, Nigeria. Afr. J. Biotechnol. 2008, 7, 3788-3791. [CrossRef]

100. Stratev, D.; Daskalov, H.; Vashin, I. Characterisation and determination of antimicrobial resistance of $\beta$-haemolytic Aeromonas spp. isolated from common carp (Cyprinus carpio L.). Rev. Med. Vet. (Toulouse) 2015, 166, 54-61.

101. CLSI. Performance Standards for Antimicrobial Susceptibility Testing, 27th ed.; CLSI supplement M100; Clinical and Laboratory Standards Institute: Wayne, PA, USA, 2017; ISBN 1-56238-1-56238-805-3.

102. Elexson, N.; Afsah-Hejri, L.; Rukayadi, Y.; Soopna, P.; Lee, H.Y.; Tuan Zainazor, T.C.; Nor Ainy, M.; Nakaguchi, Y.; Mitsuaki, N.; Son, R. Effect of detergents as antibacterial agents on biofilm of antibiotics-resistant Vibrio parahaemolyticus isolates. Food Control 2014, 35, 378-385. [CrossRef]

103. Osundiya, O.; Oladele, R.; Oduyebo, O. Multiple Antibiotic Resistance (MAR) indices of Pseudomonas and Klebsiella species isolates in Lagos University Teaching Hospital. Afr. J. Clin. Exp. Microbiol. 2013, 14, 164-168. [CrossRef]

104. Hayat Mahmud, Z.; Kassu, A.; Mohammad, A.; Yamato, M.; Bhuiyan, N.A.; Nair, G.B.; Ota, F. Isolation and molecular characterization of toxigenic Vibrio parahaemolyticus from the Kii Channel, Japan. Microbiol. Res. 2006, 161, 25-37. [CrossRef] [PubMed]

105. Stratev, D.; Gurova, E.; Vashin, I.; Daskalov, H. Multiplex PCR detection of haemolysin genes in $\beta$-haemolytic Aeromonas hydrophila strains isolated from fish and fish products. Bulg. J. Agric. Sci. 2016, 22, 308-314. 